
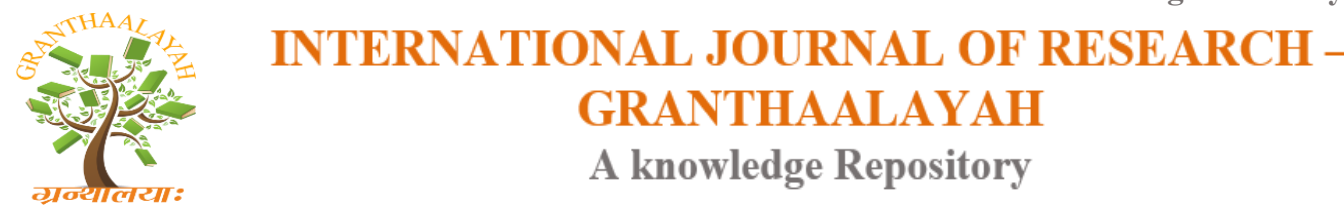

Science

\title{
EXPERIMENTAL STUDY AND PERFORMANCE OF PV SYSTEM AND PEDAL POWER WITH GRID
}

\author{
Priyanka Suman Verma ${ }^{1}$, Dr. A.K.Sharma ${ }^{2}$ \\ ${ }^{1}$ Research scholar, Fourth Semester ME (High Voltage Engg.), Jabalpur Engineering College, \\ Jabalpur (M.P) 482011, INDIA \\ ${ }^{2}$ Professor \& HOD, Department of Electrical Engineering, Jabalpur Engineering College, \\ Jabalpur (M.P) 482011, INDIA
}

\begin{abstract}
A solar cell is essential a PN junction with a large surface area. The $N$-type material is kept thin to allow light to pass through to the PN junction. Light travels in packets of energy called photons. The generation of electric current happens inside the depletion zone of the PN junction. The depletion region as explained previously with the diode is the area around the $P N$ junction where the electrons from the $N$-type silicon, have diffused into the holes of the $P$ type material. 3.2.3- Pedal power-

Some applications include pedal powered laptops, pedal powered grinders and pedal powered water wells. Some third world development projects currently transform used bicycles into pedal powered tools for sustainable development. The articles on this page are about the many wonderful applications for pedal power technology.
\end{abstract}

Keywords:

photovoltaic cells, energy storage system.

Cite This Article: Priyanka Suman Verma, and Dr. A.K.Sharma, "EXPERIMENTAL STUDY AND PERFORMANCE OF PV SYSTEM AND PEDAL POWER WITH GRID” International Journal of Research - Granthaalayah, Vol. 4, No. 4 (2016): 159-164.

\section{INTRODUCTION}

A photon of light is absorbed by one of these atoms in the N-Type silicon it will dislodge an electron, creating a free electron and a hole. The free electron and hole has sufficient energy to jump out of the depletion zone. If a wire is connected from the cathode (N-type silicon) to the anode (P-type silicon) electrons will flow through the wire. The electron is attracted to the positive charge of the P-type material and travels through the external load (meter) creating a flow of electric current. The hole created by the dislodged electron is attracted to the negative charge of N-type material and migrates to the back electrical contact. As the electron enters the P-type silicon from the back electrical contact it combines with the hole restoring the electrical neutrality. 
Photovoltaic solar cells are thin silicon disks that convert sunlight into electricity. These disks act as energy sources for a wide variety of uses, including: calculators and other small devices; telecommunications; rooftop panels on individual houses; and for lighting, pumping, and medical refrigeration for villages in developing countries. Solar cells in the form of large arrays are used to power satellites and, in rare cases, to provide electricity for power plants.

When research into electricity began and simple batteries were being made and studied, research into solar electricity followed amazingly quickly. As early as 1839, Antoine-Cesar Becquerel exposed a chemical battery to the sun to see it produce voltage. This first conversion of sunlight to electricity was one percent efficient. That is, one percent of the incoming sunlight was converted into electricity.

Willoughby Smith in 1873 discovered that selenium was sensitive to light; in 1877 Adams and Day noted that selenium, when exposed to light, produced an electrical current. Charles Fritts, in the 1880s, also used gold-coated selenium to make the first solar cell, again only one percent efficient. Nevertheless, Fritts considered his cells to be revolutionary. He envisioned free solar energy to be a means of decentralization, predicting that solar cells would replace power plants with individually powered residences.

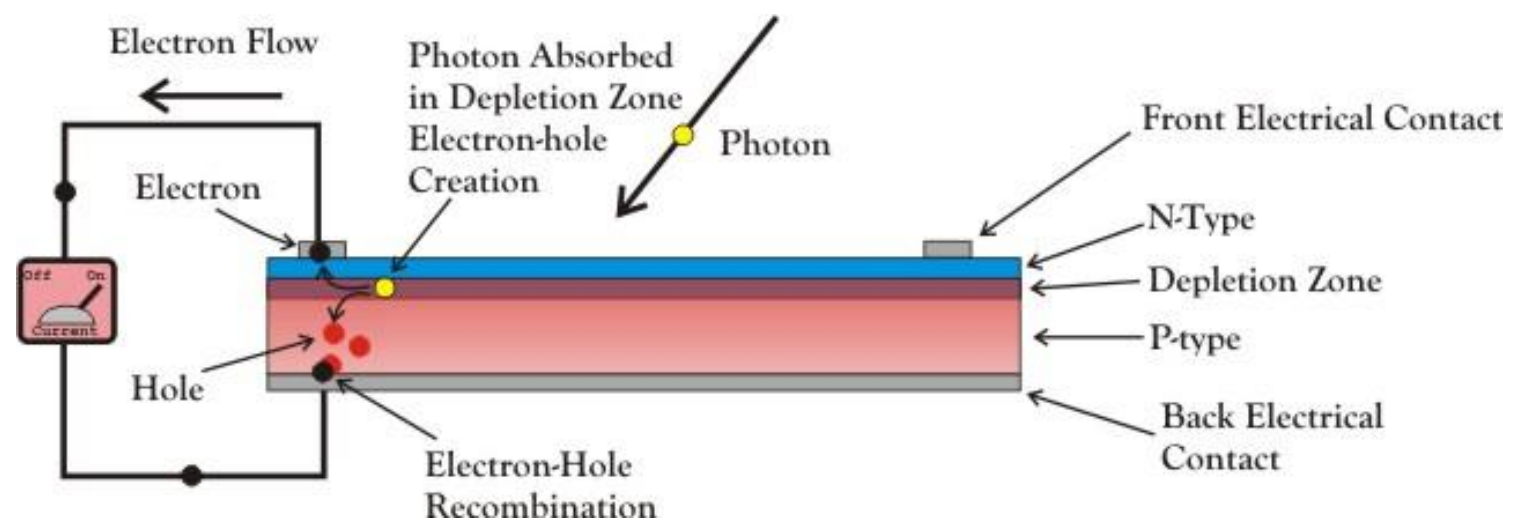

Figure 1: Solar Cell

\section{EXPERIMENTAL SETUP}

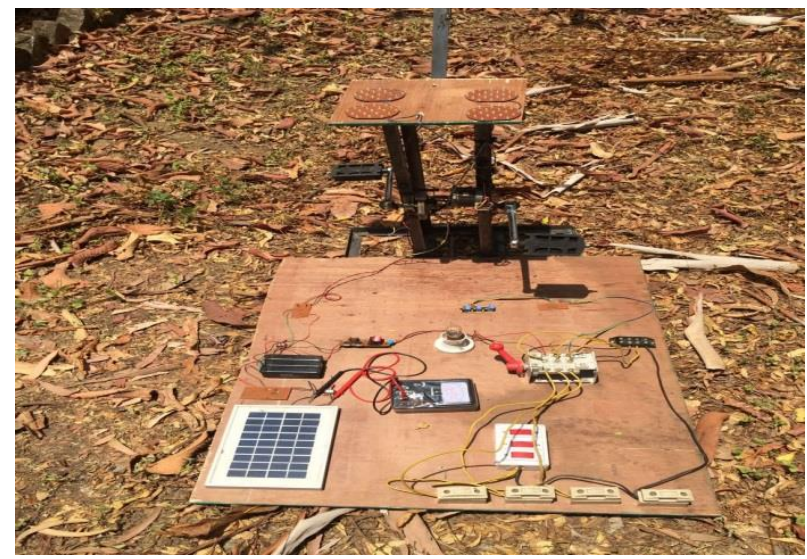

Figure 2: Experimental stepup 


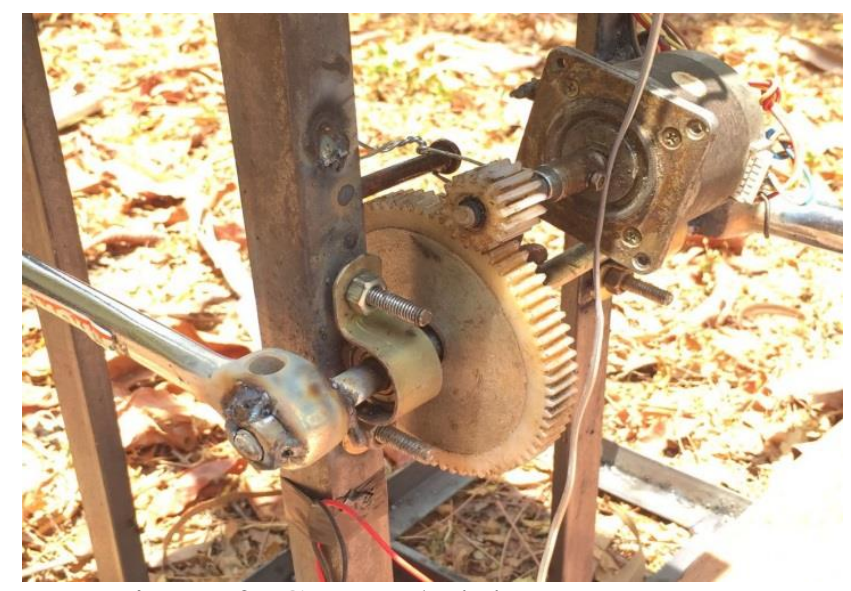

Figure 3: Gear and pinion arrangement

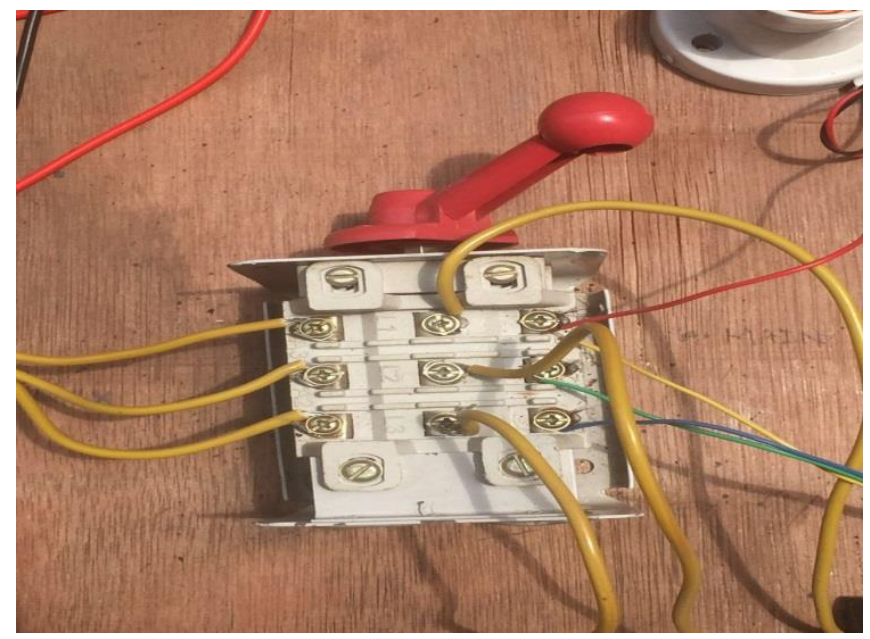

Figure 4: Grid Connector

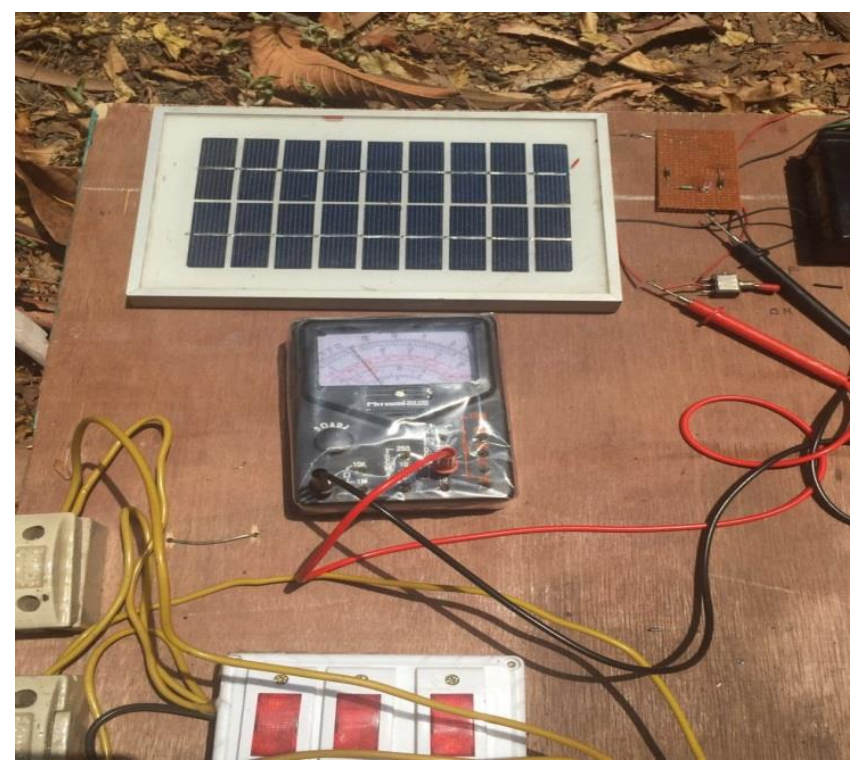

Figure 5: solar power generation 


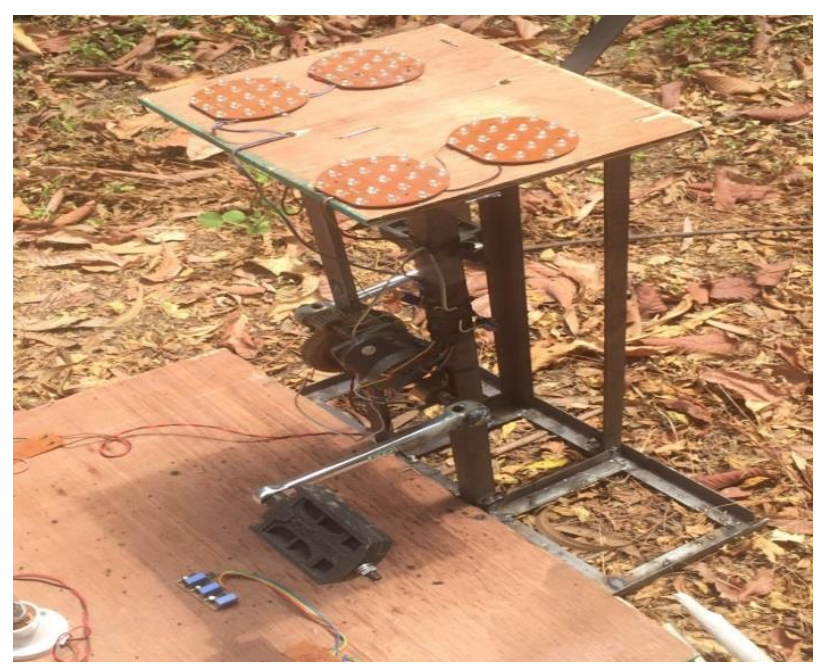

Figure 6: LED display

\section{RESULT AND DISCUSSION}

Table 1: Voltage with respect to time using of solar cells

\begin{tabular}{|l|l|l|}
\hline Sr.No. & Time & Voltage \\
\hline 1 & $10: 00$ & 7 \\
\hline 2 & $11: 00$ & 9 \\
\hline 3 & $12: 00$ & 11 \\
\hline 4 & $13: 00$ & 12 \\
\hline 5 & $14: 00$ & 11 \\
\hline 6 & $15: 00$ & 8 \\
\hline 7 & $16: 00$ & 6 \\
\hline
\end{tabular}

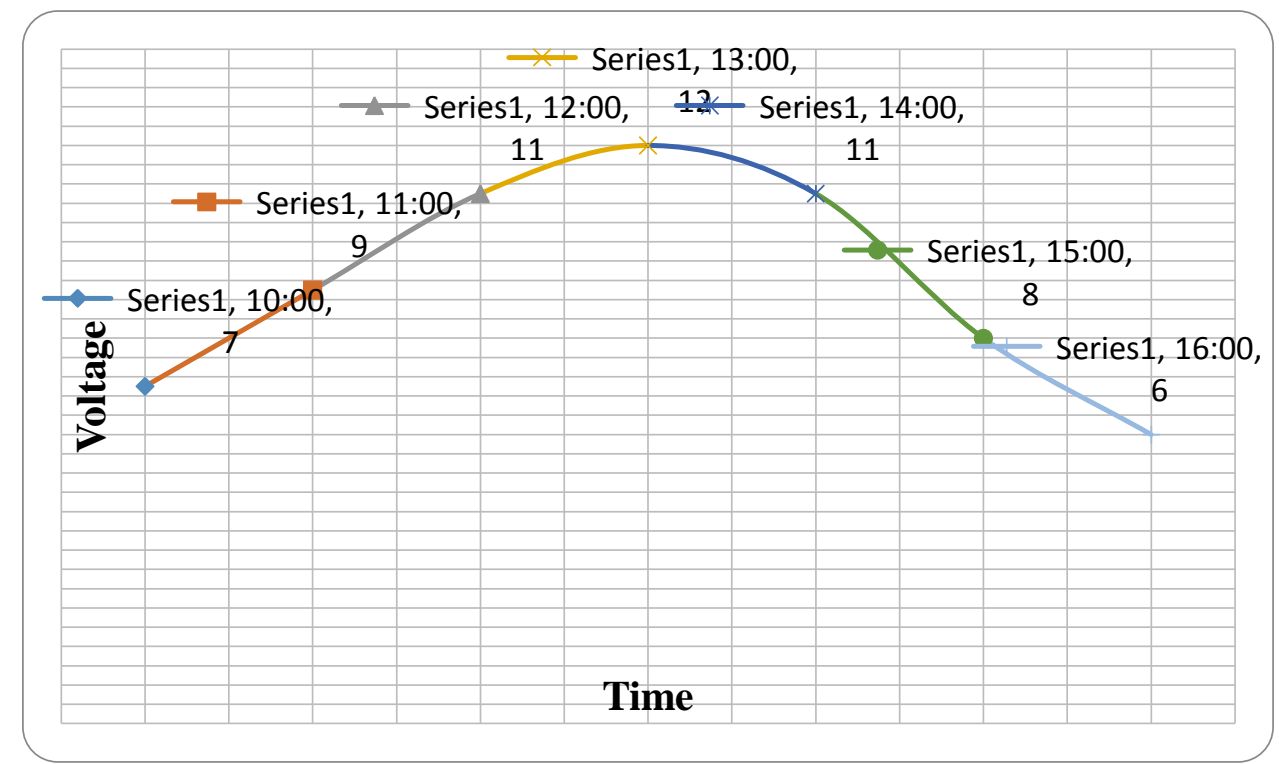

Figure 7: Voltage with respect to time using of solar cells 
Table 2: Voltage with respect to time and connected with D.C. convertor

\begin{tabular}{|l|l|l|}
\hline Sr.No. & Time & Voltage \\
\hline 1 & $10: 00$ & 7 \\
\hline 2 & $11: 00$ & 9 \\
\hline 3 & $12: 00$ & 10 \\
\hline 4 & $13: 00$ & 11 \\
\hline 5 & $14: 00$ & 10 \\
\hline 6 & $15: 00$ & 8 \\
\hline 7 & $16: 00$ & 6 \\
\hline
\end{tabular}

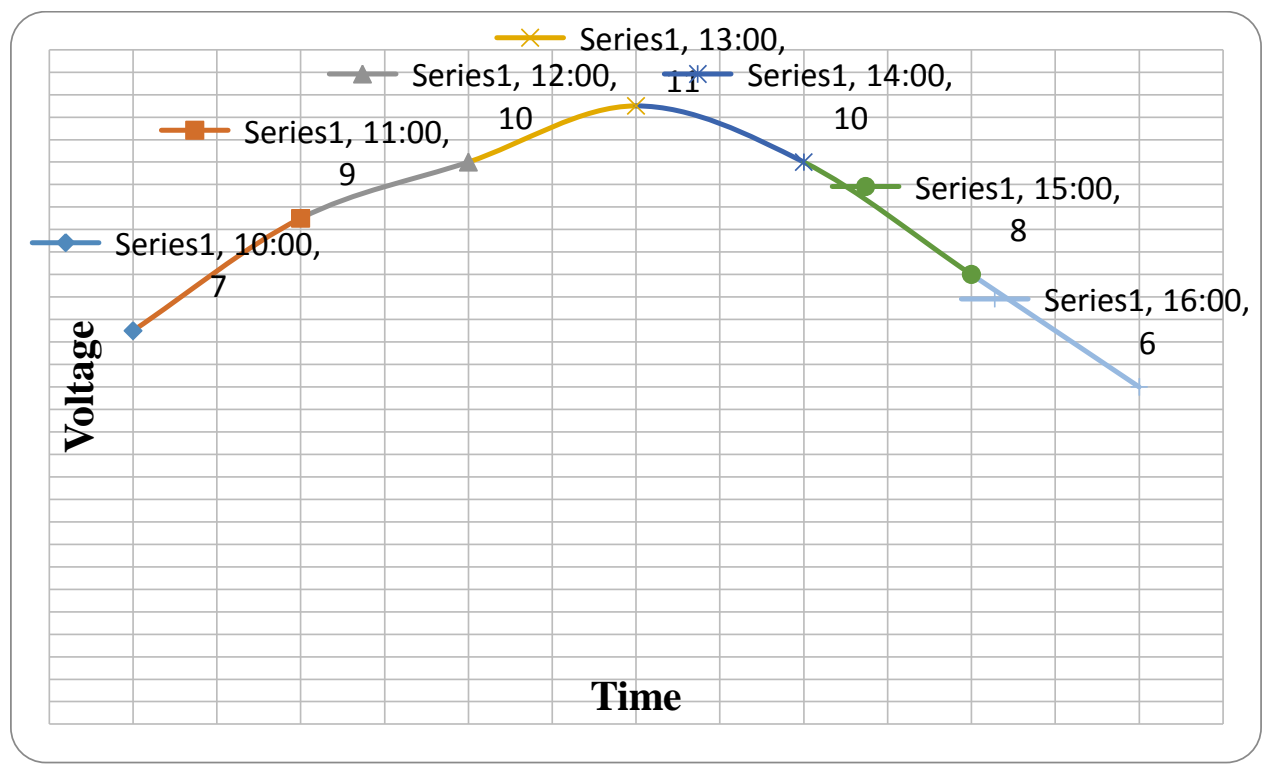

Figure 8: Voltage with respect to time and connected with D.C. convertor

Table 3: RPM of A.C. generator and Voltage

\begin{tabular}{|l|l|l|}
\hline Sr. No. & RPM of A.C. generator & Voltage \\
\hline 1 & 10 & 12 \\
\hline 2 & 20 & 17 \\
\hline 3 & 30 & 20 \\
\hline 4 & 40 & 20 \\
\hline 5 & 50 & 20 \\
\hline
\end{tabular}




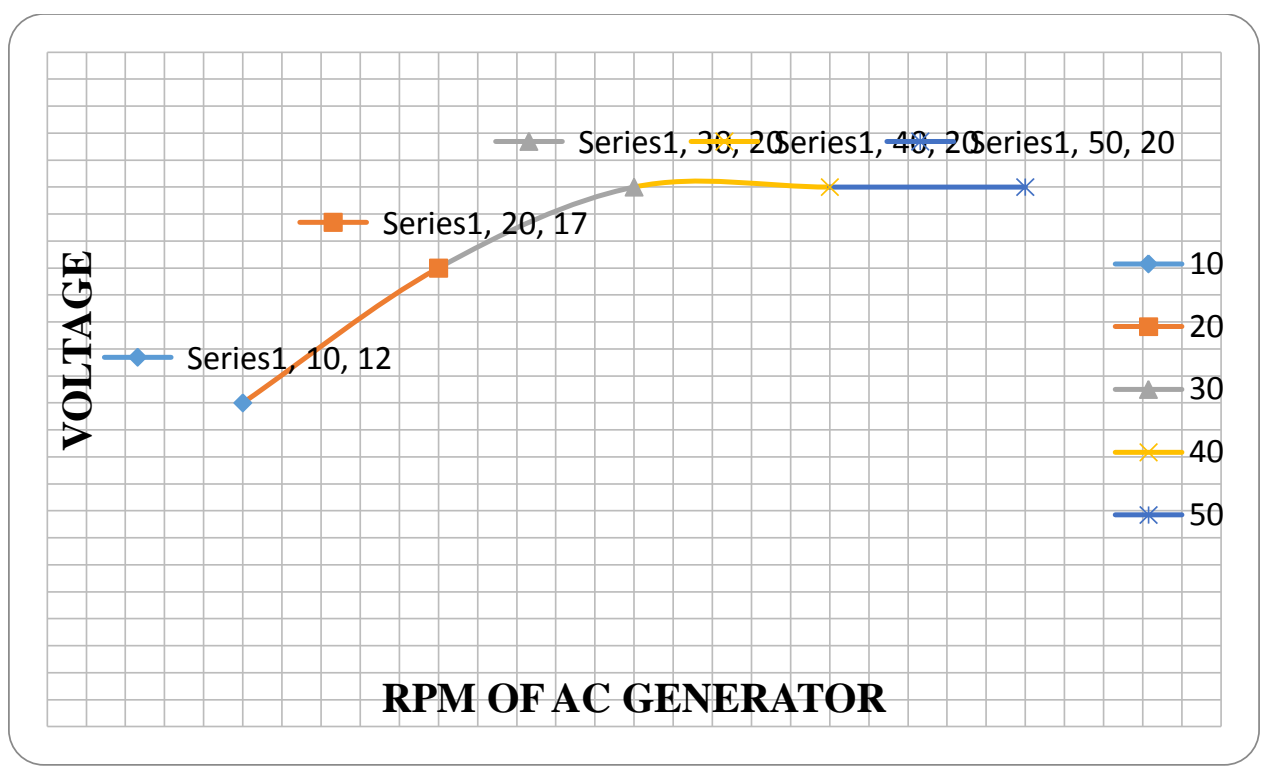

Figure 9: RPM of A.C. generator and Voltage

\section{CONCLUSION}

Generate power through pedaling by operating home appliances by pedal power tries to give autonomy to household away from grid, exercise and good health to household member. We are find out the Output Voltage are 18V DC with load and using of Rectifier by 30 RPM and Output Ampere are 3 Ampere.

\section{REFERENCE}

[1] P. D. Lund, "Impacts of energy storage in distribution grids with high penetration of photovoltaic power, ” Int. J. Distributed Energy Resources, vol. 3, no. 1, pp. 31-45, 2007.

[2] A. Morimoto, "Performance analyses of battery integrated grid-connected residential PV systems, ” in Proc. 21 st Eur. Photovolt. Sol. Energy Conf., 2006, pp. 2580-2584.

[3] H. Serban, "A control strategy for a distributed power generation microgrid application with voltage and current-controlled source converter," IEEE Trans. Power Electron., vol. 25, no. 12, pp. 2981-2992, Dec. 2010.

[4] N. Soltau, S. Thomas, and R. W. D. Doncker, "The balance of renewable sources and user demands in grids: Power electronics for modular battery energy storage systems," IEEE Trans. Power Electron., vol. 25, no. 12, pp. 3049-3056, Dec. 2010.

[5] T. Ise, "Low-voltage bipolar-type DC microgrid for super high quality distribution," IEEE Trans. Power Electron., vol. 25, no. 12, pp. 3066-3075, Dec. 2010. 